\title{
PERBANDINGAN PROPORSI ANTIBODI IREGULER PADA PASIEN MULTITRANSFUSI DAN PASIEN NON MULTITRANSFUSI DI UTD RSUP DR. MOHAMMAD HOESIN PALEMBANG
}

\author{
Comparison of the Proportion of Iregular Antibodies in Multitransfusion \\ and Non Multitransfusion Patients at UTD RSUP Dr. Mohammad Hoesin Palembang
}

\begin{abstract}
Amalia'
Zen Hafy ${ }^{2}$

Phey Liana ${ }^{3}$

IProgram Studi Magister Ilmu Biomedik Fakultas Kedokteran, Universitas Sriwijaya Jalan Raya Palembang-Prabumulih Km. 32 Inderalaya, Ogan Ilir, Sumatera Selatan, Indonesia

\author{
2,3Bagian Imunologi dan Sains \\ Transfusi, Fakultas Kedokteran, \\ Universitas Sriwijaya Palembang \\ Jalan Raya Palembang- \\ Prabumulih Km. 32 Inderalaya, \\ Ogan Ilir, Sumatera Selatan, \\ Indonesia
}

*email: zhafy@yahoo.co.id

Kata Kunci:

Antibodi leguler Identifikasi antibodi

Multitransfusi

\section{Keywords:}

Iregular antibody

Antibody Identification

Multitransfusion

\begin{abstract}
Abstrak
Antibodi ireguler atau "unexpected antibodies" merupakan antibodi selain antibodi A dan antibodi B yang dapat terjadi akibat kehamilan dan transfusi darah. Pasien yang sering melakukan transfusi (multitransfusi) lebih berisiko membentuk antibodi ireguler karena frekuensi paparan terhadap antigen sel darah merah donor lebih sering terjadi. Antibodi ireguler bermakna secara klinis karena dapat menimbulkan hemolisis (aloantibodi eritrosit), febrile non hemolytic transfusion reactions (aloantibodi leukosit), atau transfusi trombosit refrakter (aloantibodi trombosit). Tujuan dari peneltiin ini adalah untuk melihat perbandingan proporsi antibodi ireguler pada pasien multitransfusi dan pasien non multitransfusi di UTD RSUP Dr. Mohammad Hoesin Palembang. Penelitian ini merupakan studi observasional analitik dengan desain potong lintang dilakukan pada 2 kelompok subjek masing-masing 45 sampel. Dilakukan identifikasi antibodi pada setiap kelompok. Proporsi antibodi ireguler dianalisis dengan Chi-Square. Dilakukan analisa jenis antibodi yang ditemukan serta diagnosa klinis yang menyertai. Hasil dari penelitian ini didapatkan perbedaan proporsi antibodi ireguler yang signifikan antara kelompok multitransfusi dan non multitransfusi dengan nilai $p$ sebesar $0,00 \mathrm{I}$. Jenis antibodi ireguler yang ditemukan adalah anti-c, Fya, Lea, M, K $p^{a}$, Lub, K $p^{b}$ dan diagnosa klinis yang ditemukan adanya antibodi ireguler adalah anemia, Cronic Kidney Disease, Systemic Lupus Erythematosus, Multi Drug Resistance Tuberculosis, thalasemia dan Autoimun Hemolitic Anemia.
\end{abstract}

\begin{abstract}
Irregular antibodies or "unexpected antibodies" are antibodies other than antibody A and antibody $B$ that can occur as a result of pregnancy and blood transfusions. Patients who frequently perform transfusions (multitransfusions) are more at risk of forming irregular antibodies because the frequency of exposure to donor red blood cell antigens is more frequent. Irregular antibodies are clinically significant because they can cause hemolysis (erythrocyte alloantibodies), febrile non-hemolytic transfusion reactions (leukocyte alloantibodies), or refractory platelet transfusions (platelet alloantibodies). The aim of this research is to compare the proportion of irregular antibodies in multitransfusion patients and non-multitransfused patients at UTD Dr. Mohammad Hoesin Palembang. This research is an analytic observational study with a cross-sectional design conducted on 2 groups of subjects, 45 each samples. Antibody identification in each group was carried out. The proportion of irregular antibodies was analyzed by Chi-Square. An analysis of the types of antibodies found and the accompanying clinical diagnoses were carried out. The results of this study showed a significant difference in the proportion of irregular antibodies between the multitransfusion and non-multitransfusion groups with $p$ value $0.00 I$. The types of irregular antibodies found anti-c, Fya, Lea, M, Kpa, LubKpb and the clinical diagnoses that found irregular antibodies were anemia, Cronic Kidney Disease, Systemic Lupus Erythematosus, Multi Drug Resistance Tuberculosis, thalasemia dan Autoimun Hemolitic Anemia.
\end{abstract}




\section{PENDAHULUAN}

Transfusi darah merupakan salah satu perawatan kesehatan yang vital yang merupakan kegiatan pemindahan darah donor kepada pasien. Pada beberapa penyakit, seperti talasemia, anemia sickle cell, dan anemia aplastik, transfusi sel darah merah merupakan pengobatan utama (Brecher ME, 2005).

Pada proses transfusi jika seseorang mendapatkan antigen berbeda dari antigen pada tubuhnya, maka tubuhnya akan membentuk antibodi yang dapat menyebabkan reaksi berupa hemolisis baik intravaskular maupun ekstravaskular. Secara alami, pada serum atau plasma orang normal hanya terdapat antibodi $A$ dan antibodi $B$ yang disebut juga sebagai antibodi alamiah, sedangkan selain dari pada itu merupakan "unexpected antibodies" atau antibodi ireguler (Wilkins R, 20II).

Antibodi ireguler yang ditemukan pada pasien dapat berupa autoantibodi maupun aloantibodi yang terbentuk akibat paparan terhadap antigen yang tidak dimiliki oleh pasien ketika mendapatkan transfusi darah atau riwayat kehamilan sebelumnya. Pada pasien yang sering melakukan transfusi lebih berisiko membentuk antibodi ireguler karena frekuensi paparan terhadap antigen sel darah merah donor lebih sering terjadi. Antibodi ireguler yang dihasilkan dari aloimunisasi bermakna secara klinis jika antibodi tersebut dapat menimbulkan hemolisis (aloantibodi eritrosit), febrile non hemolytic transfusion reactions (aloantibodi leukosit), atau transfusi trombosit refrakter (aloantibodi trombosit) (Ness PM, 2000; Zwaginga JJ, 2017).

Frekuensi antibodi ireguler bervariasi antar populasi dengan frekuensi yang telah dilaporkan sekitar 2-21 \%. Frekuensi antibodi ireguler pada kelompok pasien multitransfusi contohnya pada pasien thalasemia dan sel sabit dapat mencapai $50 \%$. Alloantibodi ini disebabkan karena kehamilan sekitar 0,24 \% sedangkan karena transfusi darah kejadiannya lebih tinggi (Novelli Em,2017; Jungbauer C, 2012). Frekuensi antibodi ireguler eritrosit di Indonesia pada populasi umum belum diketahui. Namun, pada pasien thalasemia telah dilakukan beberapa penelitian didapatkan frekuensi antibodi ireguler berkisar antara 8-29,5 \% (Meriska, 2016).

Deteksi antibodi ireguler penting pada resipien karena antibodi ireguler dapat menyebabkan berbagai permasalahan seperti mengganggu pemeriksaan crossmatch, menghambat ketersediaan produk darah, memboroskan tenaga dan biaya penyediaan unit darah yang cocok, dapat memperpendek usia hidup eritrosit donor, dan berpotensi menyebabkan reaksi transfusi hemolitik (Reid M, 2016). Pada pasien multitransfusi adanya antibodi ireguler dapat menyebabkan target transfusi tidak tercapai akibat hemolisis eritrosit donor sehingga dapat meningkatkan frekuensi transfusi (Chou ST, 20I2).

Pemeriksaan uji pratransfusi salah satunya adalah identifikasi antibodi yang sebaiknya dilakukan berdasarkan rekomendasi World Health Organization (WHO, 2009). Uji identifikasi antibodi ini secara rutin sudah dilakukan di Amerika, Eropa, maupun beberapa negara di Asia seperti Jepang, Malaysia, Thailand dan Singapura, sedangkan di Indonesia masih menggunakan uji silang serasi mayor dan minor (Ningrum N, 20I8).

Identifikasi antibodi tidak hanya meminimalisir terjadinya reaksi transfusi pada pasien tetapi juga dapat mempercepat proses penyediaan darah bagi pasien (Trudell KS, 2014).

Pemeriksaan antibodi ireguler belum dilakukan di UTD RSUP Dr. Mohammad Hoesin Palembang. Dan berdasarkan penelusuran kepustakaan, belum ada penelitian mengenai perbandingan proporsi antibodi ireguler pada pasien multitransfusi dan pasien non multitransfusi di UTD RSUP Dr. Mohammad Hoesin Palembang. Berdasarkan ulasan diatas maka peneliti ingin membandingkan proporsi antibodi ireguler pada pasien multitransfusi dan pasien non multitransfusi di UTD RSUP Dr. Mohammad Hoesin Palembang sehingga dapat 
mengetahui proporsi antibodi ireguler dan jenis antibodi ireguler apa saja yang sering muncul guna penyediaan darah yang tepat dan aman untuk pasien.

\section{METODOLOGI}

Penelitian ini merupakan studi observasional analitik dengan desain potong lintang. Subjek penelitian terdiri dari 2 kelompok yakni kelompok multitransfusi dan kelompok non mulitransfusi masing-masing berjumlah 45 orang yang merupakan resipien transfusi di UTD RSUP Dr. Mohammad Hoesin Palembang yang ditentukan dengan cara non-probability consecutive sampling. Sampel penelitian merupakan plasma EDTA resipien dengan kriteria inklusi yaitu sampel dari pasien yang mendapat transfusi PRC $\geq 2$ kali untuk kelompok multitransfusi dan sampel dari pasien yang mendapat transfusi PRC $<2$ kali untuk pasien non multitransfusi.

Masing-masing sampel diperiksa identifikasi antibodi nya menggunakan alat Qwalys EVO Diagast dengan metode Erythrocytes Magnetised Technology.

\section{HASIL DAN PEMBAHASAN}

Gambaran hasil karakteristik demografi responden penelitian meliputi jenis kelamin, usia dan golongan darah disajikan dalam tabel berikut.

Tabel I. Distribusi Frekuensi Karakteristik Demografi

\begin{tabular}{|c|c|c|c|}
\hline \multirow[b]{2}{*}{ Variabel } & \multicolumn{2}{|c|}{ Jumlah Sampel } & \multirow[b]{2}{*}{$P$} \\
\hline & Multitransfusi & $\begin{array}{c}\text { Non } \\
\text { Multitransfusi }\end{array}$ & \\
\hline \multicolumn{4}{|l|}{ Jenis Kelamin } \\
\hline - Laki-Laki & $15(33,3 \%)$ & I8 (40 \%) & $0,5 I 2^{a}$ \\
\hline - Perempuan & $30(66,7 \%)$ & $27(60 \%)$ & \\
\hline Usia (Tahun) & \multicolumn{2}{|c|}{$34,04 \pm 19,99$} & \\
\hline - Bayi (0-I Tahun) & $0(0 \%)$ & $4(8,8 \%)$ & \\
\hline $\begin{array}{l}\text { - Anak-anak (2-10 } \\
\text { Tahun) }\end{array}$ & $9(20 \%)$ & $2(4,5 \%)$ & \\
\hline $\begin{array}{l}\text { - Remaja (II-19 Tahun) } \\
\text { - Dewasa (20-60 } \\
\text { Tahun) }\end{array}$ & $\begin{array}{c}7(15,5 \%) \\
24(53,3 \%)\end{array}$ & $\begin{array}{c}2(4,5 \%) \\
30(66,7 \%)\end{array}$ & $0,016^{a}$ \\
\hline $\begin{array}{l}\text {-Lanjut Usia } \quad(>60 \\
\text { Tahun) }\end{array}$ & $5(11,2 \%)$ & $7(15,5 \%)$ & \\
\hline \multicolumn{4}{|l|}{ Golongan Darah } \\
\hline$-A$ & $9(20 \%)$ & I5 (33,3\%) & \\
\hline$-B$ & II (24,4 \%) & $12(26,7 \%)$ & $0,373 a$ \\
\hline
\end{tabular}

$\begin{array}{lll}-A B & 6(13,3 \%) & 6(13,3 \%) \\ -0 & 19(42,3 \%) & 12(26,7 \%)\end{array}$

Resipien transfusi yang menjadi sampel pada penelitian ini, didominasi oleh pasien yang berjenis kelamin perempuan (Tabel I). Hal ini sesuai dengan data Rikesdas tahun 2018 bahwa perempuan lebih rentan mengalami anemia dibanding laki-laki yang merupakan indikasi awal seseorang mendapatkan transfusi darah. Pada penelitian ini rerata usia sampel adalah 34,04 $\pm 19,99$ tahun dengan sampel terbanyak berada pada rentang usia 20-60 tahun, baik pada kelompok multitransfusi maupun non multitransfusi (Tabel I). Rentang usia tersebut merupakan rentang usia produktif pada kehidupan manusia. Pada rentang usia tersebut, seseorang biasanya mendapat peranan baru pada kehidupan sosialnya, berbagai kegiatan dilakukan pada usia tersebut sehingga kemungkinan untuk terjadinya hal-hal yang menyebabkan seseorang itu mendapat transfusi darah menjadi tinggi.

Golongan darah sistem $\mathrm{ABO}$ pada penelitian ini didominasi oleh golongan darah $\mathrm{O}$ sebesar $42,3 \%$ pada kelompok multitransfusi. Golongan darah $\bigcirc$ merupakan golongan darah sistem $\mathrm{ABO}$ paling banyak dibandingkan golongan darah sistem $A B O$ lainnya pada semua ras di dunia (3I-5I\%). Berbeda dari kelompok multitransfusi, pada kelompok non multitransfusi golongan darah $\mathrm{A}, \mathrm{B}$ dan $\mathrm{O}$ dengan persentase yang hampir sama sedangkan golongan darah $A B$ merupakan golongan dengan persentase terkecil. Hal ini sesuai dengan data nasional Kemendagri tahun 2018 bahwa hanya 6,7 persen dari populasi rakyat Indonesia mempunyai golongan darah $A B$ (Kemendagri, 20I8). 
Tabel II. Distribusi Karakeristik Diagnosa Klinis

\begin{tabular}{lcc}
\hline \multirow{2}{*}{ Variabel } & \multicolumn{2}{c}{ Jumlah Sampel } \\
\cline { 2 - 3 } & Multitransfusi & $\begin{array}{c}\text { Non } \\
\text { Multitransfusi }\end{array}$ \\
\hline \hline Diagnosa Klinis & $2(4,4 \%)$ & $0(0 \%)$ \\
- Infeksi & $8(17,9 \%)$ & $2(4,4 \%)$ \\
- Neoplasma & $27(60 \%)$ & $0(0 \%)$ \\
- Kelainan Hematologi & $0(0 \%)$ & $2(4,4 \%)$ \\
termasuk sistem imun & $0(0 \%)$ & $3(6,7 \%)$ \\
- Endokrin Metabolik & $3(6,7 \%)$ & $7(15,6 \%)$ \\
- Penyakit Sistem & & \\
Pernafasan & $1(2,2 \%)$ & $17(37,8 \%)$ \\
- Penyakit Sistem & $0(0 \%)$ & $7(15,6 \%)$ \\
Pencernaan & $2(4,4 \%)$ & $0(0 \%)$ \\
- Komplikasi kehamilan, & $2(4,4 \%)$ & $0(0 \%)$ \\
persalinan dan nifas & $0(0 \%)$ & $5(11,1 \%)$ \\
- Cedera dan Keracunan & $0(0 \%)$ & $2(4,4 \%)$ \\
- Gangguan Hati & & \\
- Gangguan Ginjal & & \\
- Post Tindakan & & \\
- Diagnosa Lain & &
\end{tabular}

Besaran sampel yang terkait dalam penelitian ini baik kelompok multitransfusi maupun non multitransfusi memiliki diagnosis klinis yang menyertainya. Diagnosa terbanyak pada pasien multitransfusi adalah kelainan hematologi termasuk sistem imun. Hal ini dikarenakan transfusi merupakan pengobatan utama pada pasien dengan kelainan hematologi. Berbeda pada kelompok non multitransfusi, komplikasi kehamilan, persalinan dan nifas merupakan diagnosa terbanyak resipien transfusi.

Menurut WHO, prevalensi ibu hamil yang mengalami anemia sekitar 35-75 \% serta semakin meningkat sesuai dengan pertambahan usia kehamilan. Jika anemia pada saat kehamilan tidak diatasi maka berisiko terjadinya perdarahan pasca persalinan. Pada beberapa kasus diperlukan transfusi darah untuk mengatasi komplikasi yang mungkin terjadi .

Tabel III. Analisis Bivariat Antibodi Ireguler terhadap Jumlah Transfusi

\begin{tabular}{lccc}
\hline \multicolumn{1}{c}{$\begin{array}{c}\text { Identifikasi } \\
\text { Antibodi } \\
\text { Ireguler }\end{array}$} & $\begin{array}{c}\text { Multitrans } \\
\text { fusi }\end{array}$ & $\begin{array}{c}\text { Jumlah Sampel } \\
\text { Multitrans } \\
\text { fusi }\end{array}$ & $P$ \\
\cline { 2 - 3 } Positif & $10(22,2 \%)$ & 0 & \\
Negatif & $35(77,8 \%)$ & $45(100 \%)$ & $\mathbf{0 , 0 0 ~ I ~}^{\mathbf{a}}$ \\
Total & $\mathbf{4 5 ( 1 0 0 \% )}$ & $\begin{array}{c}\mathbf{4 5}(100 \\
\%)\end{array}$ & \\
\hline
\end{tabular}

Berdasarkan uji bivariat yang telah dilakukan hasilnya menunjukkan adanya perbedaan proporsi antibodi ireguler yang signifikan antara kelompok multitransfusi dan non multitransfusi dengan nilai $p$ sebesar 0,00 I (Tabel III.) dimana antibodi ireguler yang positif hanya ditemukan pada pasien multitransfusi.

Pasien dengan multitransfusi memiliki tingkat aloimunisasi (terbentuknya antibodi ireguler) yang tinggi karena tatalaksana pasien multitransfusi seperti thalassemia, anemia sickle cell, anemia aplastik utamanya adalah transfusi darah seumur hidup sehingga memungkinkan pasien tersebut terpapar antigen sel darah merah donor yang terus menerus ( Jungbauer, 2012; Dean Laura, 2005). Hal ini menunjukan bahwa semakin sering seseorang terpapar antigen asing maka kemungkinan untuk terbentuk aloantibodi atau antibodi ireguler semakin besar. Sesuai dengan penelitian Fridawati et.al tahun 2016 yang menemukan bahwa interval transfusi darah yang lebih sering pada pasien thalasemia berpotensi lebih besar terbentuk antibodi ireguler. Hasil yang berbeda ditemukan pada penelitian Perwitasari et.al tahun 2017 yang menyimpulkan bahwa hanya I,I\% pasien Transfusion Dependent Thalassemia yang membentuk antibodi ireguler.

Perbedaan hasil penelitian kemungkinan disebabkan oleh faktor kompleks lain yang berperan menimbullkan antibodi ireguler seperti imunogenitas antigen, dossage effect serta status imunitas resipien.

Tabel IV. Distribusi Sampel Berdasarkan Jenis Antibodi

\begin{tabular}{lcc}
\hline \multirow{2}{*}{ Jenis Antibodi } & \multicolumn{2}{c}{ Pasien Multitransfusi } \\
\cline { 2 - 3 } & $\mathbf{N}$ & $\%$ \\
\hline $\mathrm{C}$ & 4 & 40 \\
$\mathrm{Fy}^{\mathrm{a}}$ & $\mathrm{I}$ & 10 \\
$\mathrm{Le}^{\mathrm{a}}$ & $\mathrm{I}$ & 10 \\
$\mathrm{M}$ & $\mathrm{I}$ & 10 \\
$\mathrm{Kp}^{\mathrm{a}}$ & $\mathrm{I}$ & 10 \\
$\mathrm{Lu}^{\mathrm{b}}, \mathrm{Kp} \mathrm{p}^{\mathrm{b}}$ & 2 & 20 \\
Total & 10 & 100
\end{tabular}


Antibodi c proporsi yang paling sering ditemukan sebanyak $40 \%$ dari pasien multitransfusi yang meminta darah di UTD RSUP Dr. Mohammad Hoesin Palembang. Antibodi c merupakan antibodi sistem Rhesus, dimana antibodi sistem rhesus paling sering ditemukan setelah sistem $A B O$. Hal serupa ditemui pada penelitian Ningrum et.al yang menyimpulkan sebanyak $59 \%$ resipien transfusi mempunyai antibodi rhesus diantaranya anti-E, e, C dan c (Ningrum, 2018).

Tabel V. Distribusi Diagnosa Klinis terhadap pembentukan Antibodi Ireguler

\begin{tabular}{lcc}
\hline \multirow{2}{*}{ Diagnosa Klinis } & \multicolumn{2}{c}{ Pasien Multitransfusi } \\
\cline { 2 - 3 } & N & $\%$ \\
\hline Anemia & 4 & 40 \\
CKD & 2 & 20 \\
SLE & 1 & 10 \\
MDR TB & 1 & 10 \\
Thalassemia & 1 & 10 \\
AlHA & 1 & 10 \\
Total & 10 & 100 \\
\hline
\end{tabular}

Anemia merupakan diagnosa terbanyak pasien dengan antibodi ireguler. Anemia merupakan salah satu masalah kesehatan di seluruh dunia terutama negara berkembang. Saat ini diperkirahan $30 \%$ penduduk dunia menderita anemia. Anemia bisa disebabkan oleh defisiensi zat gizi, infeksi akut dan kronis, juga kelainan hemolitik. Pada pasien anemia transfusi merupakan pengobatan utama sehingga paparan antigen donor lebih sering terjadi dan berpotensi lebih besar untuk membentuk antibodi ireguler.

\section{KESIMPULAN}

Proporsi antibodi ireguler pada pasien multitransfusi dan pasien non multitransfusi berbeda signifikan $(p<0,05)$. Antibodi ireguler hanya ditemukan pada pasien multitransfusi, hal ini menandakan bahwa semakin sering seseorang menerima transfusi darah maka semakin besar kemungkinan terbentuk antibodi ireguler. Diketahui variasi antibodi ireguler pada subjek penelitian dapat digunakan untuk menentukkan kebijakan pemberian transfusi pada pasien multitransfusi serta menentukkan donor darah yang tepat untuk pasien tersebut.

Disarankan perlu dilakukan penelitian selanjutnya dengan menganalisa status imun resipien serta faktor lain yang memicu terbentuknya antibodi ireguler.

\section{UCAPAN TERIMA KASIH}

Kami mengucapkan terima kasih kepada seluruh Civitas Akademika Program Studi Magister Ilmu Biomedik Fakultas Kedokteran Universitas Sriwijaya atas segala bantuan dan dukungannya. Kami berharap dapat memberikan informasi yang berguna di kemudian hari.

\section{REFERENSI}

I. Brecher, M.E. 2005. Technical Manual $15^{\text {th }}$. American Association of Blood Banks (AABB). US. p. 483-520.

2. Chou ST, Liem RI, Thompson AA. 2012.Challenges of alloimmunization in patients with haemoglobinopathies. $\mathrm{Br} J$ Haematol. Nov; I59(4):394-404.

3. Dean, Laura M.D. 2005. Blood Groups and Red Cell Antigens. National Center for Biotechnology Information (NCBI).

4. Fridawati V, Triyono T, Sukorini U. 2016. Faktor Kebahayaan Terbentuknya Alloantibodi pada Pasien Talasemia yang Menerima Transfusi Darah Berulang. Indonesian Journal of Clinical Pathology and Medical Laboratory IJCPML; $\quad 20 \quad$ (3);।I6-I30. https://indonesianjournalofclinicalpathology.or

5. Irfannuddin, 2019. Cara Sistematis Berlatih Meneliti. Edisi Pertama. Rayana Komunikasindo. Jakarta.

6. Jungbauer C, Hobel CM, Schwartz DWM, Mayr WR. 20I2. High-throughtput multiplex PCR genotyping for 35 red blood cell antigens in blood donors. Vox Sang;102(3):23442.https://onlinelibrary.wiley.com. 
7. Merizka E. 2016. Profil Antigen Sel Darah Merah dan Aloantibodi pada Pasien Talasemia di Pusat Talasemia Rumah Sakit Dr. Ciptomangunkusumo (RSCM) Program Studi Magister IImu Biomedik.

8. Ness, PM. 2000. Transfusion Medicine: An Overview and Update.ClinChem;46(8 Pt 2):I270-6. https://pubmed.ncbi.nlm.nih.gov

9. Ningrum NR, Ritchie NK, Syafitri R. 2018. Skrining dan Identifikasi Antibodi Pasien di UTD PMI. Pinlitamas. Jakarta.

10. Novelli EM. 2017. Blood Transfusion in the Management of Patients with Haemoglobinopathies. In: Murphy MF, Rob-erts DJ, Yazer MH. Practical Transfusion Medicine. 5 th p. 330-8.

II. Perwitasari E, Dalimonthe NZ, Lismayanti L, Andiyoko B. 2017. Gambaran Hasil Screening Aloantibodi pada Pasien Tranfusion Dependent Thalassemia di RSUP Dr. Hasan Sadikin Bandung. Fakultas Kedokteran Universitas Padjajaran. Bandung

12. Reid ME, Lomas FC. 2016. Erythrocyte Antigens and Antibodies In: Kaushansky K, Lichtman MA, Prchal JT, Levi MM, Press OW, Burns LJ, et al. William HematologyNineth Edition. McGraw-Hill Education. New York. p. 2329-5I.

13. Reid, M. E. 2003. The Dombrock blood group system: a review. Transfusion, 43(I), I07-II4. doi:I0.1046/j. I537-2995.2003.00283.x

14. Rikesdas. 2018. Laporan Hasil Riset Kesehatan Dasar. Balitbangkes. Jakarta

15. Trudell, KS. 20I4. Detection and Identification of Antibodies. In: Harmening, DM. Modern Blood Banking \& Transfusion Practices $6^{\text {th }}$.US. p. 216240.

16. WHO, 2009. Detection and identification of antibodies. Safe Blood and Blood Product.WHO.Genewa. P. 38-44. https://www.who.int/bloodsafety/transfusion.p df
17. Wilkins, R. 20II. Antibody Identification. School of Health Related Proffesions, University of Missisipi Medical Center. https://austincc.edu

18. Zwaginga JJ, Ham SMv. 2017. Essential Immunology for Trans-fusion Medicine. In: Murphy MF, Roberts DJ, Yazer MH. Practical Transfusion Medicine $5^{\text {th }}$ P. II-8. 